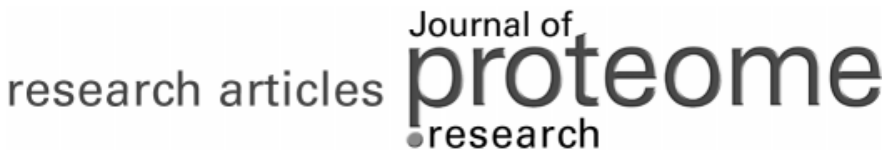

\section{Proteomic Identification of PKC-Mediated Expression of 20E-Induced Protein in Drosophila melanogaster}

\author{
Yaning Sun, ${ }^{\dagger}$ Shiheng An, ${ }^{\dagger}$ Vincent C. Henrich, ${ }^{\ddagger}$ Xiaoping Sun, ${ }^{\S}$ and Qisheng Song*,† \\ Division of Plant Sciences, 1-31 Agriculture Building, University of Missouri, Columbia, Missouri 65211, Center \\ for Biotechnology, Genomics, and Health Research, 3703 MHRA Building, University of North Carolina, \\ Greensboro, North Carolina 27402, and Laboratory of Experimental Gerontology, National Institute on Aging, \\ 6200 Seaforth Street, Baltimore, Maryland 21224
}

Received August 10, 2007

\begin{abstract}
Ecdysone receptor (EcR) and its heterodimeric partner, ultraspiracle protein (USP), are nuclear receptors that mediate the action of the insect molting hormone 20-hydroxyecdysone (20E). There is evidence that the activity of both receptors is affected by phosphorylation. Using a proteomic approach, we have shown that protein kinase $\mathrm{C}$ (PKC) activity is necessary for mediating 20E-induced expression of 14 specific proteins, including three previously reported $20 \mathrm{E}$ responsive proteins, and is also responsible for the intracellular localization of EcR and USP in larval salivary glands of Drosophila melanogaster. The 20E-dependent expression of the proteins was verified using real-time PCR and/or Western blot analysis. For some genes, inhibition of PKC activity reduced 20E-dependent transcriptional activity rapidly, raising the possibility that these are direct gene targets of EcR and USP. The data further indicate that PKC-mediated phosphorylation is also required for genes regulated indirectly by $20 \mathrm{E}$-induced changes in the larval salivary gland.
\end{abstract}

Keywords: nuclear receptor • protein expression • protein kinase • inhibitor

\section{Introduction}

Insect steroid hormones, mainly 20-hydroxyecdysone (20E), trigger and coordinate the molting and metamorphosis of insects via ecdysone receptor (EcR) and its heterodimer ultraspiracle protein (USP). ${ }^{1,2}$ Both EcR and USP are members of the nuclear receptor superfamily and are ligand-activated transcription factors. The activities of nuclear receptors are subjected to regulation not only by transcriptional/translational mechanisms but also by posttranslational mechanisms such as phosphorylation. Studies of transcription factors in vertebrates have shown that phosphorylation can play roles in nuclear translocation, DNA binding, interactions with other proteins, and transactivation. ${ }^{3,4}$

In insects, both EcR and USP have been demonstrated to be phosphoproteins and EcR and USP phosphorylation are regulated by 20E. ${ }^{-8}$ Phosphorylation of EcR and USP has been shown to play roles in mediating the ligand- and perhaps also DNA-binding activity in the prothoracic glands of M. sexta. 20Einduced expression and phosphorylation of a specific isoform of USP in the Manduca prothoracic glands has been associated with changes in ecdysteroidogenic activity both in vivo and in vitro, ${ }^{5}$ suggesting a feedback mechanism by which ecdysteroid synthesis is downregulated. Thus, phosphorylation provides

* To whom correspondence should be addressed. Phone: (573)-882-9798. Fax: (573)-882-1469. E-mail: SongQ@missouri.edu.

$\dagger$ University of Missouri.

‡ University of North Carolina.

${ }^{\S}$ National Institute on Aging. another layer of mechanism to regulate the function of the EcR/ USP complex.

For studies of ecdysteroid action, the larval salivary gland (SG) of Drosophila melanogaster has been extensively studied as a model for unraveling the hierarchy of cellular response to steroid hormones. Briefly, specific genes within these SGs incubated with $20 \mathrm{E}$ rapidly undergo changes in transcriptional activities that are mediated by the functional EcR/USP heterodimer. Later, the transcription of these early genes regresses as the transcription of late genes is induced by early gene products. ${ }^{9}$ Recently, protein kinase C (PKC) activity has been shown to be necessary for USP phosphorylation in the larval SG of $D$. melanogaster. Inhibition of PKC activity by a PKCspecific inhibitor, chelerythrine chloride (CC), inhibits transcription of early 20E-induced genes, including E74A, E75B, DHR3, and the late genes, including E78A and E78B. Nevertheless, inhibition of PKC activity does not affect other genes that are not induced by 20E. ${ }^{10}$ The involvement of a PKC signaling pathway in 20E-induced gene transcription is further supported by its requirement for the receptor of activated $C$ kinase 1 (RACK1), a shuttling protein that translocates the activated PKC to appropriate subcellular sites for target protein phosphorylation. ${ }^{11,12}$ RACK1 is necessary for 20E-induced expression of the transcription factor CHR3 in the spruce budworm Choristoneura fumiferana. ${ }^{13}$

Although EcR and USP phosphorylation has been implicated in mediating the ligand- and DNA-binding activities of the EcR/ USP complex and PKC has been shown to be involved in 20Einduced gene transcription, little is known about the roles of 
PKC in mediating the subcellular translocation of EcR and USP and 20E-induced protein expression in D. melanogaster. In the present study with the larval SG of $D$. melanogaster, several novel 20E-induced proteins have been identified using a proteomic approach. The transcription of genes encoding these proteins display characteristics of both early and late responsive genes, and their induction is reduced by inhibiting PKC activity. Further, PKC activity plays a role in mediating subcellular translocation of $D$. melanogaster EcR and USP, suggesting a mechanism for at least some of these transcriptional outcomes.

\section{Materials and Methods}

Insects. D. melanogaster (wild type ${ }^{\text {ore }}$ ) was reared on artificial blue diet (Fisher Scientific, catalog no. 22315) at $24{ }^{\circ} \mathrm{C}$ under constant darkness. The blue diet allows easy synchronization of the early wandering third instar larvae based on the protocol described by Andres and Thummel, ${ }^{14}$ and the synchronized early wandering third instar larvae were used for the following experiments.

Immunohistochemical Localization of EcR and USP in PKC Inhibitor-Treated Glands. To investigate the effect of PKCspecific inhibitor chelerythrine chloride (CC) on EcR and USP subcellular localization, SGs from early wandering larvae were dissected under Ringer's solution $(3.6 \mathrm{mM} \mathrm{NaCl}, 54.3 \mathrm{mM} \mathrm{KCl}$, $8.0 \mathrm{mM} \mathrm{CaCl}_{2}$, and $28.3 \mathrm{mM} \mathrm{MgCl}_{2}$ ) and immediately placed in a 12 -well tissue culture plate containing $500 \mu \mathrm{L}$ of Grace's insect tissue culture medium. After dissection, the medium was carefully removed from the well and replaced with $500 \mu \mathrm{L}$ of fresh Grace's medium containing the indicated concentrations of PKC-specific inhibitor CC and incubated for $6 \mathrm{~h}$ at room temperature. The control group was incubated with Grace's medium only. For study of temporal response, SGs were incubated with $100 \mu \mathrm{M}$ CC for 3, 6, 12, and $24 \mathrm{~h}$.

After incubation, the glands were fixed in freshly prepared $4 \%$ paraformaldehyde for $2 \mathrm{~h}$ and washed thoroughly with phosphate-buffered saline (PBS) (136 mM NaCl, $1.1 \mathrm{mM} \mathrm{K}_{2}$ $\mathrm{HPO}_{4}, 2.7 \mathrm{mM} \mathrm{KCl}, 8.0 \mathrm{mM} \mathrm{Na} \mathrm{HPO}_{4}, \mathrm{pH}$ 7.4) for $15 \mathrm{~min}$. The fixed SGs were permeabilized in PBS containing $0.5 \%$ Triton100 for $40 \mathrm{~min}$, then preincubated in a blocking solution $(5 \%$ bovine serum, 5\% goat serum in PBS) for $2 \mathrm{~h}$ at room temperature. The primary antibody was prepared either at a 1:200 dilution for AB11 USP-specific monoclonal antibody $(\mathrm{mAb})$ or a 1:100 dilution for DDA $2.7 \mathrm{EcR}$ mAb in 1:10 diluted blocking solution. The permeabilized SGs were incubated with either EcR or USP primary antibody overnight at $4{ }^{\circ} \mathrm{C}$, washed three times with PBS for 15 min the following day, and then incubated with secondary antibody (goat antimouseAlexa Fluor 568) at a 1:400 dilution in a 1:10 diluted blocking solution for $2 \mathrm{~h}$. After briefly washing with PBS, SGs were incubated with SYTOX Green nucleic acid stain (Molecular Probes, catalog no. S7020) for 15 min followed by three washes with PBS before being mounted on coverslides with Aqueous Mounting Medium (Permafluor). EcR and USP signals were observed with a BioRad confocal system (BioRad Radiance 2000) at the Molecular Cytology Core of the University of Missouri-Columbia.

Western Blot Analysis of the Effect of CC on EcR and USP Distribution in Cytosolic and Nuclear Fractions. SGs of early wandering third instar larvae were dissected and cultured in Grace's medium containing $100 \mu \mathrm{M}$ PKC inhibitor CC for $6 \mathrm{~h}$ at room temperature. The control group received Grace's medium only (CC was dissolved in water). After incubation, cytosolic and nuclear proteins were prepared from the SGs according to a modified protocol by Alnemri et al. ${ }^{15}$ Briefly, SGs from each treatment were collected into a $1.5 \mathrm{~mL}$ tube, respectively, washed with fresh Grace's medium twice, and resuspended in $100 \mu \mathrm{L}$ of cell lysing buffer (50 mM HEPE, pH7.4, 1 mM PMSF, 1\% NP40). After 10 min incubation on ice, the SGs were centrifuged at $1000 \mathrm{~g}$ for $10 \mathrm{~min}$ and supernatant was collected as cytosolic protein preparation. The pellet was briefly rinsed with the cell lysing buffer to remove remaining cytosolic proteins and added with $100 \mu \mathrm{L}$ of nuclei extraction buffer (20 mM HEPES, pH 7.4, $5 \mathrm{mM} \mathrm{KCl,} 0.5 \mathrm{mM}$ DTT, 0.5 $\mathrm{mM} \mathrm{MgCl}$, $0.6 \mathrm{M} \mathrm{NaCl}$ ). Following incubation on ice for 15 min with occasional vortex, the sample was centrifuged at $16000 \mathrm{~g}$ for $15 \mathrm{~min}$. Supernatant was collected as soluble nuclei protein fraction, and the pellet was briefly rinsed with the nuclear lysing buffer and collected as the nuclear pellet.

Protein concentration was determined using the BioRad protein bioassay kit (reagent A: catalog no. 500-0113; reagent B: catalog no. 500-0114), and protein samples were subjected to SDS-PAGE and Western blot analysis using AB11 USP mAb (1:1000) and DDA 2.7 EcR mAb (1:500), respectively, as described previously. ${ }^{8}$

2D Gel Analysis of 20E-Induced Proteins in PKC InhibitorTreated Glands. SGs from early wandering third instar larvae were dissected in Ringer's solution and preincubated in Grace's medium for $30 \mathrm{~min}$ in the presence or absence of $100 \mu \mathrm{M}$ PKC inhibitor CC and then stimulated with or without $0.5 \mu \mathrm{M} 20 \mathrm{E}$ (a predetermined effective dose) for $6 \mathrm{~h}$. At the end of incubation, the SGs were collected, homogenized, and centrifuged at $16000 \mathrm{~g}$ for $10 \mathrm{~min}$. Protein concentration in the resulting supernatant was quantified as described above. The resulting protein samples from each treatment were subjected to 2D gel electrophoresis and Coomassie blue staining as described previously. ${ }^{10}$ In brief, the first dimensional isoelectric focusing (IEF) was performed using BioRad Protein IEF cell and ReadyStrip IPG strips ( $\mathrm{pH} 3-7,11 \mathrm{~cm}$, BioRad catalog 01654000) according to the manufacturer's instructions. Each IPG strip was soaked in a rehydration buffer containing $100 \mu \mathrm{g}$ of total protein per treatment. After isoelectric focusing, the IPG strip was equilibrated and subjected to SDS-PAGE (8-16\% TrisHCL gradient gel, BioRad catalog 0345-0105) and Coomassie blue (G-250) staining.

In-Gel Protein Digestion. Coomassie blue-stained 2D gels were compared between the treatments, and differentially displayed protein spots were identified. Protein spots that were induced or enhanced by $20 \mathrm{E}$ but inhibited by the PKC inhibitor were excised from the $2 \mathrm{D}$ gel using a $1 \mathrm{~mm}$ diameter metal punch. The excised gel pieces were subjected to in-gel digestion according to the standard protocol provided by the MU Proteomics Center (modified from Havlis et al. ${ }^{16}$ and Jiménez et al. $\left.{ }^{17}\right)$. Briefly, the excised gel pieces were moved to clean $1.5 \mathrm{~mL}$ Safe-Lock eppendorf tubes (Eppendorf, catalog no. 022363204) and destained three times with $500 \mu \mathrm{L}$ of $50 / 50$ (v/v) acetonitrile/100 mM ammonium bicarbonate solution for $15 \mathrm{~min}$ at RT with agitation and washed briefly in $500 \mu \mathrm{L}$ of acetonitrile. Gel pieces were then dehydrated for $20 \mathrm{~min}$ with $500 \mu \mathrm{L}$ of acetonitrile (RT, with agitation) and rehydrated for 2 $\mathrm{h}$ at $4{ }^{\circ} \mathrm{C}$ in $5 \mu \mathrm{L}$ of a $20 \mu \mathrm{g} / \mathrm{mL}$ solution of modified TPCKtreated porcine trypsin (Trypsin Gold, mass spectrometry grade, 17 000U/mg, catalog no. V5280, Promega, Madison, WI) in 40 $\mathrm{mM}$ ammonium bicarbonate/10\% acetonitrile. Subsequently, the trypsin solution was replaced with $15 \mu \mathrm{L}$ of $40 \mathrm{mM}$ ammonium bicarbonate $/ 10 \%$ acetonitrile, and the proteins were digested overnight at $37^{\circ} \mathrm{C}$. The digests were acidified by 
Table 1. Real-Time PCR Primers for Verifying the Identified Proteins

\begin{tabular}{|c|c|c|}
\hline primer name & forward & reverse \\
\hline 1. GD & 5'-GAGGACTACAAGAACGAGCAC-3' & 5'-GAATGACCAGGATGTTGCGAT-3' \\
\hline 2. ATPase B & 5'-GTCCGTGCTGGATGACCACAC-3' & 5'-GTCGGTAAGGATGACCAGCA-3' \\
\hline 3. FBP1 & 5'-AACCTGCCCACCGTTAGCG-3' & 5'-TGCTGGACTCCGAAAGTGC-3' \\
\hline 4. LP07910 & $5^{\prime}$-CGTTAGCGTGAACAGTGAC-3' & $5^{\prime}$-TGCTGGACTCCGAAAGTGC-3' \\
\hline 5. mATP synthase B & 5'-CAGAAGCGTTCCACCGTCGCT-3' & 5'-GCAACAGGGACATCTGACG-3' \\
\hline 6. GA 17461 & 5'-GCCAACTTCCTCAAGGTCGTGTC-3' & 5'-GCCGTCCATCTGGTTGAGCAG-3' \\
\hline 7. eIF-4a & 5'-GTCGCAAGGTGGACCAACTG-3' & 5'-ACCCTTGCGACCGAAACGA-3' \\
\hline 8. LD22255 & 5'-CCACCCGTCTGGGAATCTC-3' & 5'-ACTTGGTCAGGGAGTAGCA-3' \\
\hline 9. ATPase E & 5'-CGAGGTCACCAAGAATCAG-3' & 5'-GCCTTGTATTGCTCCACAG-3' \\
\hline 10. RACK1 & 5'-TTTGTCGGTTGCCTTCTCG-3' & 5'-TCCAGACCTTGACGGTGCGAT-3' \\
\hline 11. Annexin B & 5'-CCATTGCCCAGTTCTACGA-3' & 5'-AAGGTGGACTCATCTGTGC-3' \\
\hline 12. GST & 5'-TACGGCAAGACCGACTCCСТGTA-3' & 5'-CACCAGGGCAATGTCGGCTAC-3' \\
\hline 13. LP02306p & $5^{\prime}$-GTTATTGGCCGTTTCGTGGT-3' & 5'-TGGTTTGCTGTTCTCCGCTG-3' \\
\hline 14. HADH & 5'-AACATCAATACCGTGGGCACGT-3' & 5'-CCCTGGGTGCTCAAGTCAC-3' \\
\hline DHR3 (+ ctl) & 5'-CCGCTCAAGGGCGATGTCA-3' & 5'-AAACGACATTCGGGTGCTG-3' \\
\hline FTZ-F1A $(-\mathrm{ctl})$ & 5'-CGGAGCGGTCGTGCCACAT-3' & 5'-ACCACGCATTCTATCCGCTCGA-3' \\
\hline Rp49 (CK) & 5'-TACAGGCCCAAGATCGTGAA-3' & 5'-GACAATCTCCTTGCGCTTCT-3' \\
\hline
\end{tabular}

addition of $4 \mu \mathrm{L}$ of extraction solvent and were transferred into $500 \mu \mathrm{L}$ tubes. Each gel piece was extracted twice with $10 \mu \mathrm{L}$ of $600 / 300 / 100(\mathrm{v} / \mathrm{v} / \mathrm{v})$ acetonitrile/water/10\% trifluroacetic acid solution for 10 min with gentle agitation at RT. Extracts from one sample were pooled, snap frozen in liquid $\mathrm{N}_{2}$, and stored at $-80^{\circ} \mathrm{C}$. The freezing extractions were dried by lyophilization and redissolved in $5 \mu \mathrm{L}$ of $0.1 \%$ TFA in $5 \%$ acetonitrile. The rehydrated samples were then concentrated and desalted using Eppendorhf Perfect pure C18 tips and eluted in $5 \mu \mathrm{L}$ of $0.1 \%$ TFA in $50 \%$ acetonitrile following the manufacturer's instructions.

MALDI-TOF Spectrometry of Tryptic Digests. Digested and ZIP-tipped samples were spotted onto a stainless-steel MALDI plate with an equal amount of CHCA matrix $(5 \mathrm{mg} / \mathrm{mL}$ in $60 \%$ ACN, $0.3 \%$ TFA, $10 \mathrm{mM}$ ammonium phosphate). An equal volume $(0.5 \mu \mathrm{L})$ of CHCA matrix was added and allowed to crystallize at room temperature. A peptide mass spectrum was acquired using Applied Biosystems 4700 proteomics analyzer, which was operated in a positive ion mode, and spectra were acquired over a mass range of 800 to 4000 Da. Peptide calibration standards (4700 calibration mix, Applied Biosystems) were used to calibrate the instrument in MS mode using six peptides of known mass. Calibration was achieved by the "plate model and default" mode for MS of six external calibrant spots. MS/MS calibration was also conducted using fragment ions of the 1570.7 Glu-1-fibrinopeptide B on all six calibrant spots. MS acquisition was conducted over an 800 to $4000 \mathrm{Da}$ mass range. Internal MS calibration using at least two trypsin autolysis peptide ions was also done when these ions were present (above signal/noise ratio of 10). Mass fingerprints were processed with the software GPS Explorer (version 3.6). Ions with $\mathrm{S} / \mathrm{N}$ ratios $>20$ (excluding trypsin autolysis) up to a maximum of 65 per spectrum were submitted for search for protein matches against the NCBInr database limited to $D$. melanogaster (last updated September 17, 2006) using the "combined MS and MS/MS" function of the GPS Explorer software. Search parameters allowed one trypsin miss-cleavage and the following modifications to peptides: carbamidomethyl cysteines and methionine oxidation.

Characterization of the Matched Protein Candidates Using Real-Time PCR and Western Blots. SGs were dissected and preincubated with $100 \mu \mathrm{M}$ PKC inhibitor CC for 30 min and then stimulated with $0.5 \mu \mathrm{M} 20 \mathrm{E}$ for $6 \mathrm{~h}$, the same conditions noted for 2D gel analysis. For real-time PCR measurements, samples were collected at 2 and $6 \mathrm{~h}$. After incubation, total RNA was isolated from each treatment using Trizol reagent (Invitrogen) according to the manufacturer's instructions, and RNA concentration was determined by measuring the absorbance at 260 $\mathrm{nm}$ on a spectrophotometer. The extracted total RNA was treated with RNase-free DNase I (Promega, catalog no. M6101) to eliminate potential contamination by genomic DNA. About $1.5 \mu \mathrm{g}$ of total RNA from each sample was used for the firststrand cDNA synthesis. The first-strand cDNA synthesis was primed using oligo (dT) based on the SuperScript First-Strand synthesis kit (Invitrogen, catalog no. 11904-018). The synthesized cDNA was used as template for estimation of gene transcription in salivary glands by real-time PCR. The 20E responsive genes and the corresponding primers used in realtime PCR are listed in Table 1.

Real-time PCR amplification and analysis were carried out on Applied Biosystems 7500 fast real-time PCR system (ABI). The final volume of reaction was $25 \mu \mathrm{L}$ using ABI SYBR Green Supermix (ABI). For real-time PCR, the reaction was held at $95{ }^{\circ} \mathrm{C}$ for $10 \mathrm{~min}$ followed by 40 cycles at $95^{\circ} \mathrm{C}$ for $15 \mathrm{~s}$, then $60{ }^{\circ} \mathrm{C}$ for $1 \mathrm{~min}$. The specificity of the SYBR Green PCR signal was confirmed by melting curve analysis and agarose gel electrophoresis. The mRNA expression was quantified using the comparative CT (cross threshold, the PCR cycle number that crosses the signal threshold) method. ${ }^{18}$ The CT of the housekeeping gene rp49 was subtracted from CT of the target gene to obtain $\triangle \mathrm{CT}$. The normalized fold changes of the target gene mRNA expression were expressed as $2^{-\Delta \Delta \mathrm{CT}}$, where $\Delta \Delta \mathrm{CT}$ is equal to $\Delta \mathrm{CT}$ treated sample $-\Delta \mathrm{CT}$ control.

Protein was extracted from the SGs preincubated with the PKC inhibitor CC for $30 \mathrm{~min}$ and stimulated with 20E for $6 \mathrm{~h}$, the same conditions noted for 2D gel analysis. Polyclonal antibodies against ATPase subunit B (1:1000) (from M. Huss, University of Osnabruck, Osnabruck, Germany) and FBP1 (1: 1000) (from Jean-Antoine Lepesant, University of Paris, Pairs, France) were used to verify translational expression of ATPase subunit B and FBP1 by Western blot as described above.

\section{Results}

Effect of PKC Inhibitor on EcR and USP Subcelluar Translocation. To investigate the effect of CC, a PKC-specific inhibitor, on EcR and USP subcellular translocation, SGs from early wandering third instar larvae were incubated for $6 \mathrm{~h}$ with the indicated concentrations of PKC-specific inhibitor CC and immunostained with EcR (DDA2.7) and USP (AB11) mAb, respectively. In freshly dissected SGs and in SGs incubated for $6 \mathrm{~h}$ in the absence of CC, both EcR and USP signals were 


\section{Antibody}
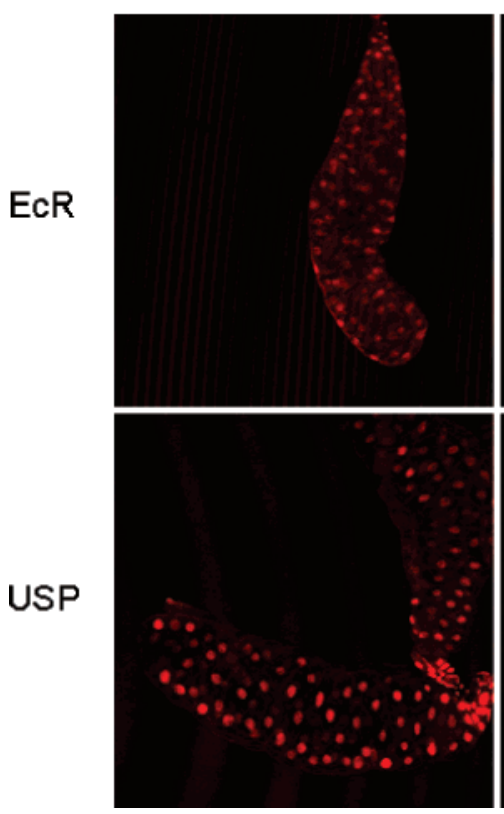

SYTOX
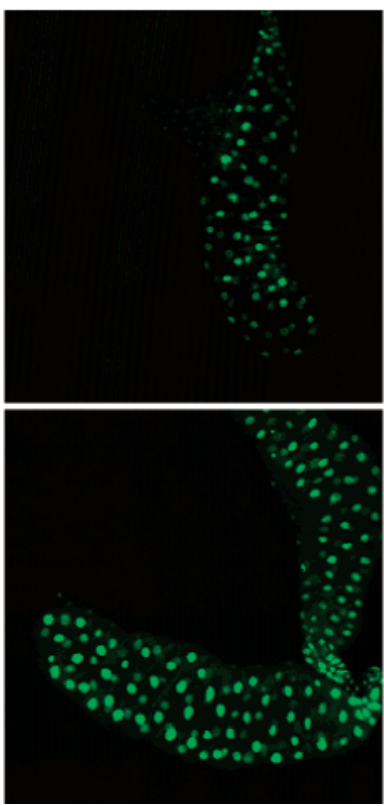

Merge
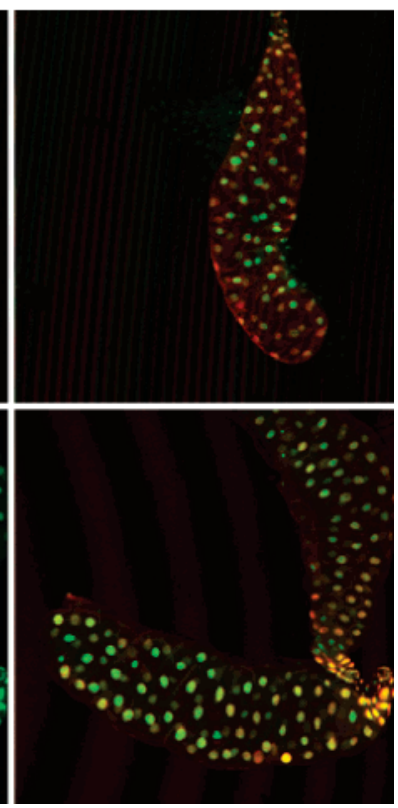

Figure 1. Immocytochemical localization of EcR and USP in the salivary glands of early wandering larvae of D. melanogaster. SGs were dissected in Grace's medium and immunostained with EcR (a) or USP (b) mAb (red color) and then counterstained with SYTOX Green nucleic acid stain (green color). EcR and USP signals were visualized using a confocal microscope (BioRad Radiance 2000) at the MU Cytology Core.

localized primarily in SG cell nuclei (Figure 1). However, when the SGs were incubated for $6 \mathrm{~h}$ with the PKC inhibitor, both EcR (Figure 2a) and USP (Figure 2b) nuclear signals declined in a dose-dependent manner starting at $25 \mu \mathrm{M}$ CC. At $50 \mu \mathrm{M}$, most EcR and USP signals disappeared and at $100 \mu \mathrm{M}$ or higher, EcR and USP signals were barely visible. The trace amount of the remaining EcR signal was mainly localized at the periphery of the nucleus, while the residual USP signal was more evenly distributed in the nucleus. Temporal response studies revealed that both EcR and USP signals started to decline when the SGs were incubated with $100 \mu \mathrm{M}$ PKC inhibitor for $3 \mathrm{~h}$ and became barely detectable when the SGs were incubated with the PKC inhibitor for $6 \mathrm{~h}$ or longer (data not shown).

To investigate whether the disappearance of EcR and USP signals from the nucleus of the PKC inhibitor-treated SGs (Figure 2a,b) was caused by the inhibition of EcR and USP protein expression by the inhibitor, the SGs were incubated for $6 \mathrm{~h}$ in the presence or absence of $100 \mu \mathrm{M}$ PKC inhibitor and lysed with specific buffer to obtain cytosolic and nuclear preparations. The latter were further treated with nuclear lysing buffer to separate the soluble nuclear fraction from the insoluble nuclear pellet. The resulting samples were analyzed by Western blot using the aforementioned EcR and USP specific antibodies. As shown in Figure 3, nearly all the signal of EcR was located in the nucleus in the absence of the PKC inhibitor, with approximately $40 \%$ in the soluble nuclear fraction (Figure 3 top panel, lane 2) and the rest in the insoluble nuclear pellet (Figure 3 top panel, lane 3). Similarly, about 50\% USP was in the cytosol (Figure 3 bottom panel, lane 1), and the rest appeared in the soluble nuclear fraction (Figure 3 bottom panel, lane 2). There was no detectable USP signal in the insoluble nuclear pellet (Figure 3 bottom panel, lane 3). As expected, both phosphorylated and nonphosphorylated forms of USP were detected in both the cytosolic and the soluble nuclear fraction (Figure 3 bottom panel, lanes 1 and 2). Phosphorylated and nonphosphorylated forms of USP in Drosophila SGs have been previously distinguished using a lambda protein phosphatase treatment assay followed by Western blot analysis. ${ }^{8}$

When the glands were incubated with the PKC inhibitor, nearly all of the EcR signal in the soluble nuclear fraction disappeared (Figure 3 top panel, lane 5) while the EcR signal in the nuclear pellet doubled (Figure 3 bottom panel, lane 6), suggesting that PKC inhibitor causes EcR to shift from the soluble nuclear fraction to the insoluble nuclear pellet. In the presence of PKC inhibitor, the phosphorylated USP form disappeared while the nonphosphorylated USP signal increased accordingly (Figure 3 bottom panel, lanes 4 and 5). The PKC inhibitor blocked USP phosphorylation and caused the shift of more than half of the USP signal from the soluble nuclear fraction to the insoluble nuclear pellet, but did not cause the shift of USP from the cytosol to the nuclear fractions. These results suggest that the PKC inhibitor does not affect the expression of EcR and USP proteins, a result that confirms a previous report. ${ }^{10}$ Nevertheless, CC affects the solubility of EcR and USP in the nucleus.

Effect of PKC Inhibitor on 20E-Induced Protein Expression. To examine whether the alteration of EcR and USP cellular solubility by the PKC inhibitor inhibited 20E-induced protein expression, SGs from early wandering larvae were preincubated with $100 \mu \mathrm{M}$ PKC inhibitor for $30 \mathrm{~min}$ and then challenged with $0.5 \mu \mathrm{M} 20 \mathrm{E}$ for $6 \mathrm{~h}$. This incubation period is sufficiently long to allow 20E-induced changes in expression that allow for the recovery of 20E-induced proteins and sufficiently short to minimize the appearance of proteins resulting from secondary cellular changes that are not directly associated with $20 \mathrm{E}$ action. At the end of the incubation, proteins were extracted from the glands and subjected to 2D gel electrophoresis, followed by Coomassie blue staining. 2D gel maps revealed approximately 41 differentially expressed protein spots: 21 induced and 20 inhibited by 20E (Figure 4a,b, not labeled). Only 14 out of the 
a.
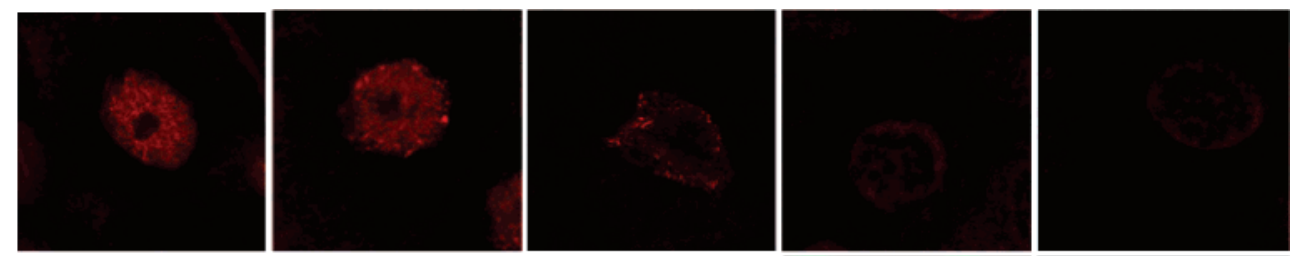

SYTOX
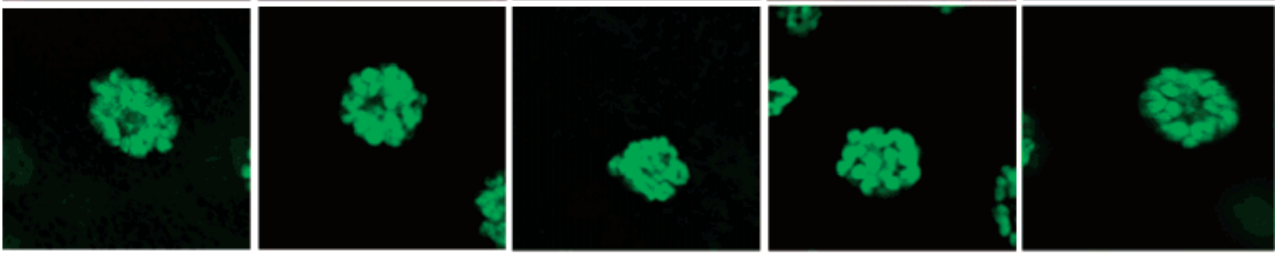

Merge

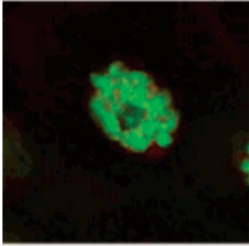

0

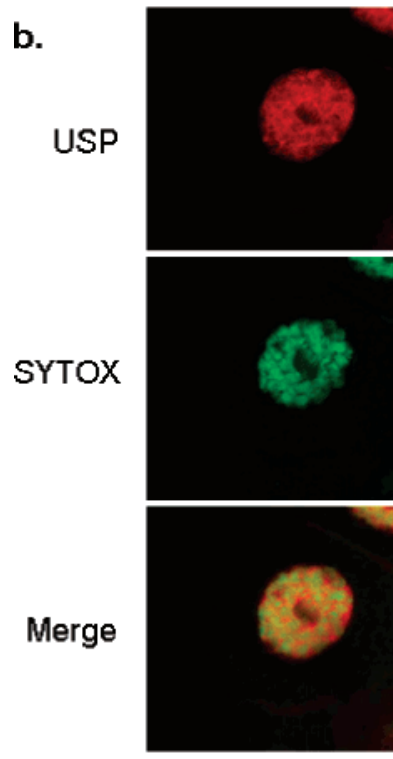

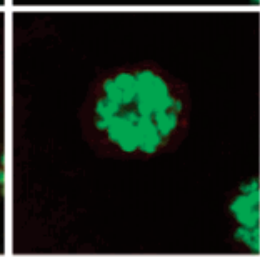

25

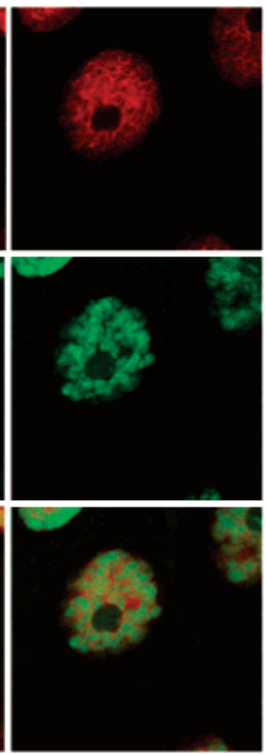

25

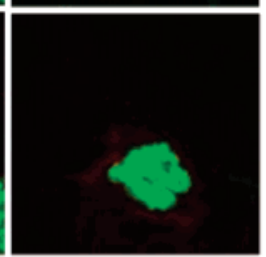

50

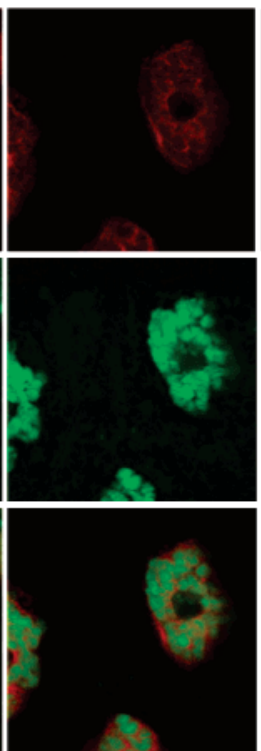

50

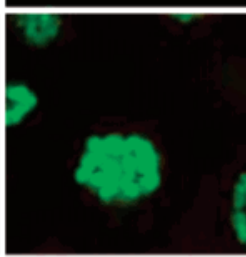

100

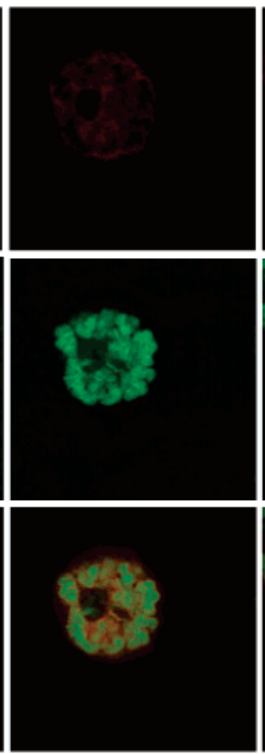

100

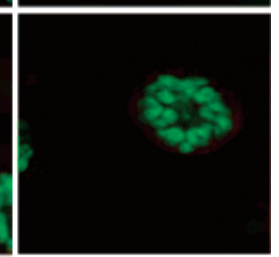

$200 \mathrm{CC}(\mu \mathrm{M})$

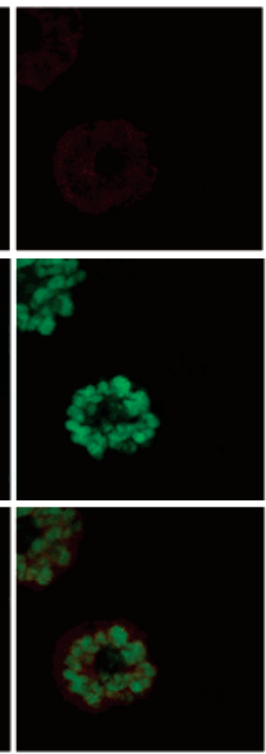

$200 \mathrm{CC}(\mu \mathrm{M})$

Figure 2. Effects of the PKC-specific inhibitor chelerythrine chloride (CC) on EcR (a) and USP (b) subcellular localization in the SGs of D. melanogaster. SGs from early wandering third instar larvae were incubated for $6 \mathrm{~h}$ in Grace's medium containing the indicated concentrations of CC and immunostained with EcR or USP mAb (red color). Nucleus of the glands was stained with SYTOX Green nuclei acid stain (green color). EcR and USP signals were visualized using a confocal microscope (BioRad Radiance 2000). At least 3-5 biological replicates were performed, and the images are typical.

21 proteins induced by $20 \mathrm{E}$ were inhibited by the additional presence of CC (Figure $4 \mathrm{~b}, \mathrm{~d}$ ). Major protein spots induced by $20 \mathrm{E}$ and inhibited by CC were labeled with numbers and excised for protein identification.

Protein Identification. 20E-induced protein spots whose induction was inhibited by CC treatment were trypsinated and subjected to MALDI-TOF MS/MS analysis. The resulting MS fingerprinting data were used to search for protein matches in the NCBInr protein databank. As shown in Figure 5a, all 14 proteins had positive match-ups in a protein databank with MASCO scores ranging from 82 to 715 (MASCO score $>60$ represents significant, $p<0.05$ ). These proteins can be roughly grouped into seven broad categories based on protein function, including protein actions, lipid metabolism, signal transduc- tion, cell protection, cell functions, storage protein, and energetics/metabolism. The relative induction ratio of these proteins by $20 \mathrm{E}$ ranged from 1 - to 5 -fold with 5 -fold representing newly induced proteins (Figure 5b), and the percent of inhibition of these proteins by CC ranged from 30 to $100 \%$ (Figure 5c) when the protein spots in the Coomassie bluestained 2D gel maps were analyzed on the basis of their relative density using an AlphaImager digital system. Five out of the 14 proteins were newly induced by $20 \mathrm{E}$, including RACK1, annexin B9a, 3-hydroxyacyl-CoA dehydrogenase, glutamate dehydrogenase, and LD22255p (Figure 5b). Their 20E-induced expression was completely blocked by CC, except for RACK1, which was only partially inhibited (approximately 60\%; Figure $5 c)$. The expression of the nine other characterized proteins 


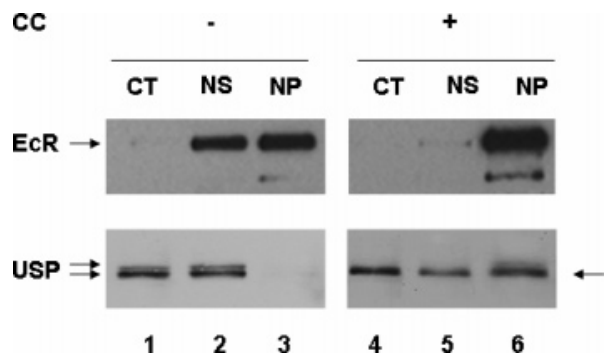

Figure 3. Western blot analysis of the effects of PKC inhibitor CC on EcR and USP subcellular distribution in the salivary glands of $D$. melanogaster. SGs from early wandering third instar larvae were incubated for $6 \mathrm{~h}$ in Grace's medium containing $100 \mu \mathrm{M}$ CC. Cytosolic and nuclear fractions were subjected to SDS-PAGE (denatured) and Western blot analysis using EcR and USP mAb. At least 3-5 biological replicates were performed, and the presented images are typical. CT: cytosol. NS: soluble nuclear fraction. NP: insoluble nuclear pellet.

was modestly affected by $20 \mathrm{E}$ (0.74- to 3.8 -fold), and in all cases, the additional presence of CC resulted in a partial reduction of quantitative protein levels (25-80\%).

Transcriptional Regulation of the Identified Proteins. The classic action of 20E involves its interaction with the EcR/USP heterodimer, which in turn affects the transcriptional activity of target genes. To confirm that the quantitative increases in protein levels registered on 2D gels (Figure 4) follow from changes in transcriptional activity associated with $20 \mathrm{E}$, we designed primers (Table 1) to all 14 proteins on the basis of a protein databank search of MALDI-TOF MS/MS data. To assess whether the changes involved early transcriptional changes that might be direct targets of ecdysteroid receptor function or later transcriptional changes that result indirectly from early changes, we examined the transcript levels after 2 and $6 \mathrm{~h}$ incubations with 20E using quantitative real-time PCR (Figure 6) and/or Western blot (Figure 7). As a control for this analysis, the early response gene, DHR3, was selected, since its promoter is a direct target of the EcR/USP heterodimer and its induction is robust. ${ }^{19}$ The induction of DHR3 by 20E is completely offset by the addition of the PKC inhibitor, suggesting that the phosphorylation state of EcR and/or USP is important for its regulation. ${ }^{10}$ Transcript levels of a second early inducible gene, E74A, was increased by about 70-fold with 20E (data not shown). E74A is strongly induced by $20 \mathrm{E}$ titers of approximately $10^{-7} \mathrm{M}$ and higher. ${ }^{20}$ As shown in Figure 6, transcripts for all 14 proteins could be grouped into four categories on the basis of their response to 20E stimulation: (1) early response, (2) late response, (3) early suppressed, and (4) late suppressed. For early response genes, transcripts of vacuolar $\mathrm{H}^{+}$-ATPase subunit B, FBP1, and LP07910p were induced by $20 \mathrm{E}$ by 1.9 - to 4.0 fold at $2 \mathrm{~h}$, and all were inhibited by the additional presence of CC. Further, the transcription of these genes was suppressed by $20 \mathrm{E}$ after $6 \mathrm{~h}$, consistent with the patterns predicted for early response genes. ${ }^{9}$ Interestingly, CC not only eliminated $20 \mathrm{E}$ induction but reduced transcript levels below the basal level
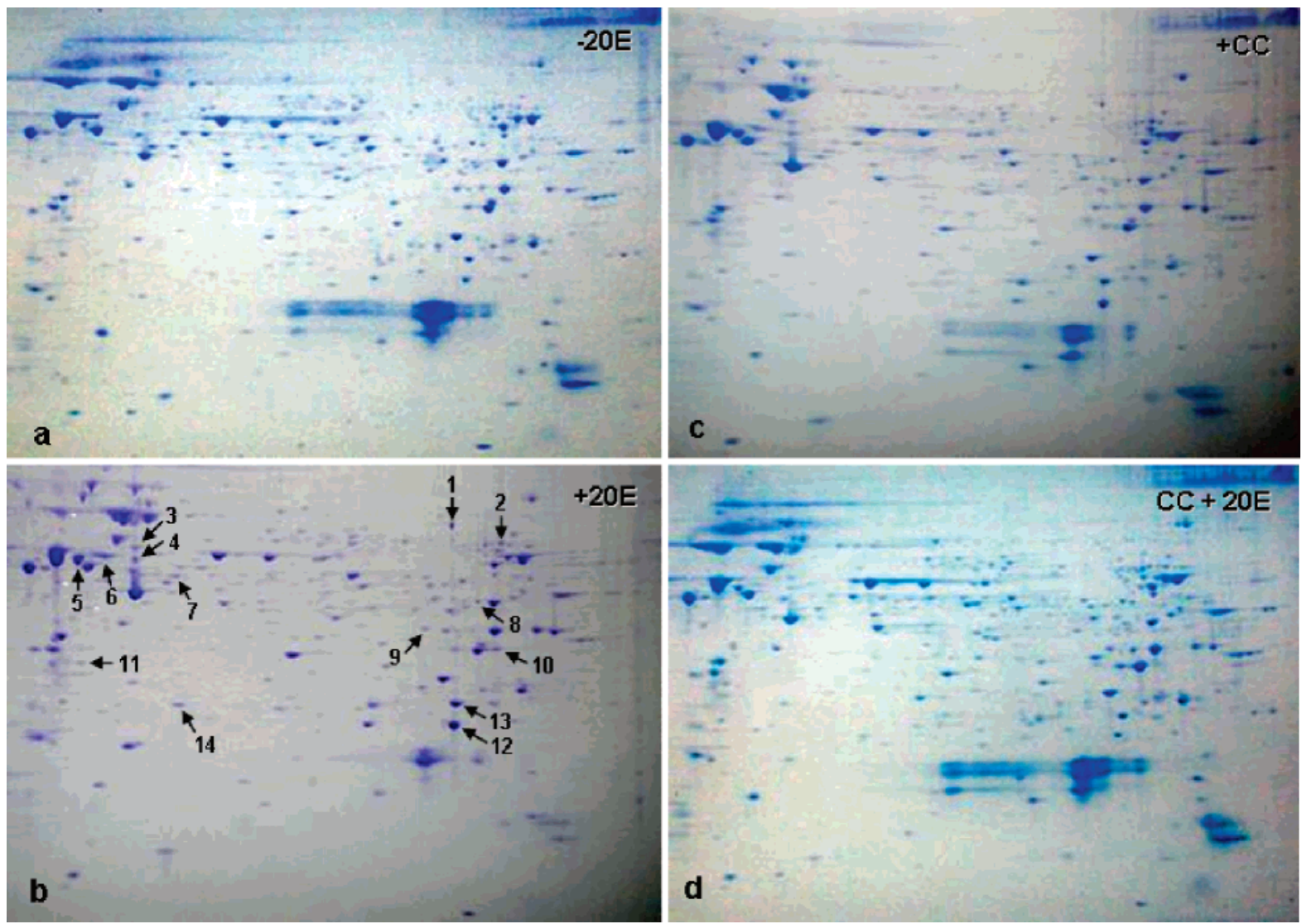

Figure 4. 2D gel analysis of PKC inhibitor CC-mediated expression of 20E-induced proteins. SGs from early wandering third instar larvae of $D$. melanogaster were preincubated for $30 \mathrm{~min}$ in the absence (a and b) or presence (c and d) of $100 \mu \mathrm{M} \mathrm{CC}$ and then challenged for $6 \mathrm{~h}$ without ( $\mathrm{a}$ and c) or with ( $\mathrm{b}$ and d) $0.5 \mu \mathrm{M}$ 20E. Proteins were extracted from each treatment and subjected to 2D gel electrophoresis and Coomassie blue (G250) staining. The proteins induced by $20 \mathrm{E}$ and blocked by CC were labeled with numbers. A minimum of three biological replicates for each treatment were performed. 


\section{a. Protein identification}

\begin{tabular}{|c|c|c|c|c|c|}
\hline Category & $\underset{H}{\text { Spot }}$ & $\begin{array}{l}\mathrm{MW} \\
(\mathrm{kDa})\end{array}$ & pl & Putative protein name & $\begin{array}{l}\text { MASCOT } \\
\text { score }\end{array}$ \\
\hline $\begin{array}{l}\text { Signal } \\
\text { transduction }\end{array}$ & 10 & 34 & 8.5 & RACK1 (gil2290597) & 177 \\
\hline $\begin{array}{l}\text { Lipid } \\
\text { metabolism }\end{array}$ & 11 & 32 & 3.7 & Annexin B9a (gil10121901) & 151 \\
\hline \multirow{6}{*}{$\begin{array}{l}\text { Energetics } \\
\text { and/or } \\
\text { metabolism }\end{array}$} & 1 & 110 & 8.0 & $\begin{array}{l}\text { Glutamate dehydrogenase } \\
\text { (gil458803) }\end{array}$ & 82 \\
\hline & 8 & 49 & 8.2 & LD22255p (gi|19528337) & 99 \\
\hline & 14 & 23 & 4.8 & $\begin{array}{l}\text { 3-hydroxyacyl-CoA dehydrogenase } \\
\text { (gi|2569966) }\end{array}$ & 132 \\
\hline & 5 & 76 & 3.7 & $\begin{array}{l}\text { Mitachondrial ATP synthase subunit } \\
\text { B (gi|1556392) }\end{array}$ & 715 \\
\hline & 2 & 80 & 8.5 & $\begin{array}{l}\text { Vacuolar H+ATPase subunit B } \\
\text { (gil24646341) }\end{array}$ & 213 \\
\hline & 9 & 40 & 7.6 & $\begin{array}{l}\text { Vacuolar H+ATPase subunit E } \\
\text { (gil24644298) }\end{array}$ & 89 \\
\hline Protein action & 6 & 77 & 4.1 & GA17461-PA (gi|54642999) & 99 \\
\hline Cell function & 7 & 62 & 4.8 & GH17619p [elF-4a] (gil21464294) & 397 \\
\hline \multirow{2}{*}{$\begin{array}{l}\text { Storage } \\
\text { protein }\end{array}$} & 4 & 70 & 4.4 & $\begin{array}{l}\text { LPO7910p (gi|27819874) = Fat body } \\
\text { protein } 1\end{array}$ & 485 \\
\hline & 3 & 80 & 4.4 & Fat body protein 1 (gi|24664085) & 172 \\
\hline Protection & 12 & 24 & 6.8 & $\begin{array}{l}\text { Glutathione S-transferase D1 } \\
\text { isoform A (gil7 299601) }\end{array}$ & 355 \\
\hline Unknown & 13 & 23 & 8.0 & LP02306p (gi|21430336) & 315 \\
\hline
\end{tabular}

b. $20 \mathrm{E}$ induced protein (fold increase)

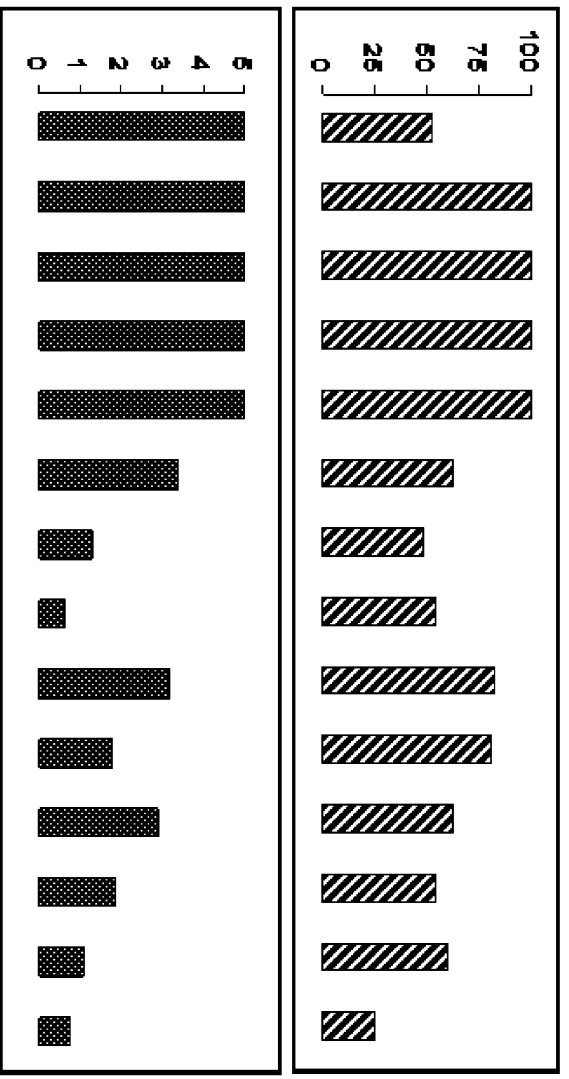

Figure 5. A list of proteins induced by $20 \mathrm{E}$ and inhibited by simultaneous CC treatment. 20E-induced and CC-blocked proteins were subjected to MALDI-TOF MS/MS analysis, and the resulting MS/MS fingerprinting data were used to search for matches against the NCBInr database. The identified proteins are listed in (a). MASCOT scores $>60$ are significant $(p<0.05)$. The ratio of induction by 20E (b) and inhibition by $\mathrm{CC}$ (c) are also given. The data represent the mean $\pm \mathrm{SE}$ of three biological samples.

in other control groups, suggesting that phosphorylation plays a role not only for increasing transcript levels but also for regulating basal transcript levels. In the late response category, $20 \mathrm{E}$ had no significant effect on the transcript levels of eIF-4a, GST, and GA17461-PA at $2 \mathrm{~h}$, but transcript levels were increased by 2.2- to 2.8-fold at $6 \mathrm{~h}$. Again, the PKC inhibitor completely blocked 20E-induced gene transcription at $6 \mathrm{~h}$. Simplistically, it follows that increases in protein levels correspond to increases in transcript levels after 2 and/or $6 \mathrm{~h}$ of 20E treatment. Paradoxically, transcript levels that are suppressed by 20E and/or PKC-inhibitor treatment are associated with some of the proteins whose levels were increased by a 6 h 20E treatment. In the early suppressed category, transcripts of LD22255, GD, RACK1, and annexin B9a were significantly inhibited by $20 \mathrm{E}$ at $2 \mathrm{~h}$ and nearly completely blocked at $6 \mathrm{~h}$. PKC inhibitor had no effect on 20E-suppressed gene transcription except that CC restored LD22255 mRNA to basal level at $6 \mathrm{~h}$ (see Discussion). For the late suppressed genes, 20E had no significant effect on mRNA levels of mitochondrial ATP synthase subunit B, vacuolar $\mathrm{H}+$-ATPase subunit E, 3-hydroxyacyl-CoA dehydrogenase, and LP02306p at $2 \mathrm{~h}$, but inhibited transcription of these genes at $6 \mathrm{~h}$. The PKC inhibitor blocked basal level transcription of mitochondrial ATP synthase subunit B, vacuolar H+-ATPase subunit E, and 3-hydroxyacylCoA dehydrogenase at $2 \mathrm{~h}$ incubation in the presence of $20 \mathrm{E}$, but not LP02306, which was enhanced by the PKC inhibitor. Interestingly, the PKC inhibitor was able to restore transcription of these genes to a basal level except ATPase subunit E (see explanation in Discussion) at $6 \mathrm{~h}$, although this effect did not depend upon 20E.

Western blot analysis was also performed to verify ATPase subunit B and FBP1 using antibodies available for these proteins. As shown in Figure 7, both ATPase subunit B and FBP1 were induced by $20 \mathrm{E}$, and this response was blocked by PKC inhibitor, a result that corresponded well with the expression of ATPase subunit B and FBP1 at the protein level as registered in 2D gel maps (Figure 4). Western blot analysis of FBP1 (Figure 7a top panel) showed four identical FBP1 bands reported by Burmester et al., ${ }^{21}$ which were all induced by $20 \mathrm{E}$ and blocked by CC, further confirming the 2D gel (Figure 4) and real-time PCR data (Figure 6). Similarly, Western blot analysis of ATPase subunit B revealed that it was induced by $20 \mathrm{E}$, but that its expression was completely blocked by CC (Figure $6 \mathrm{~b}$ bottom panel) and actually fell below the basal level. In other words, the protein levels were consistent with those seen in 2D gel maps (Figure 4), but negatively correlated to the mRNA level (Figure 6).

\section{Discussion}

PKC has previously been demonstrated to play a role in mediating the transcriptional regulation of the 20E-induced early puff gene E74A and E75B and the early late puffs, DHR3, E78A, and E78B, via the EcR/USP complex. It has no effect on 


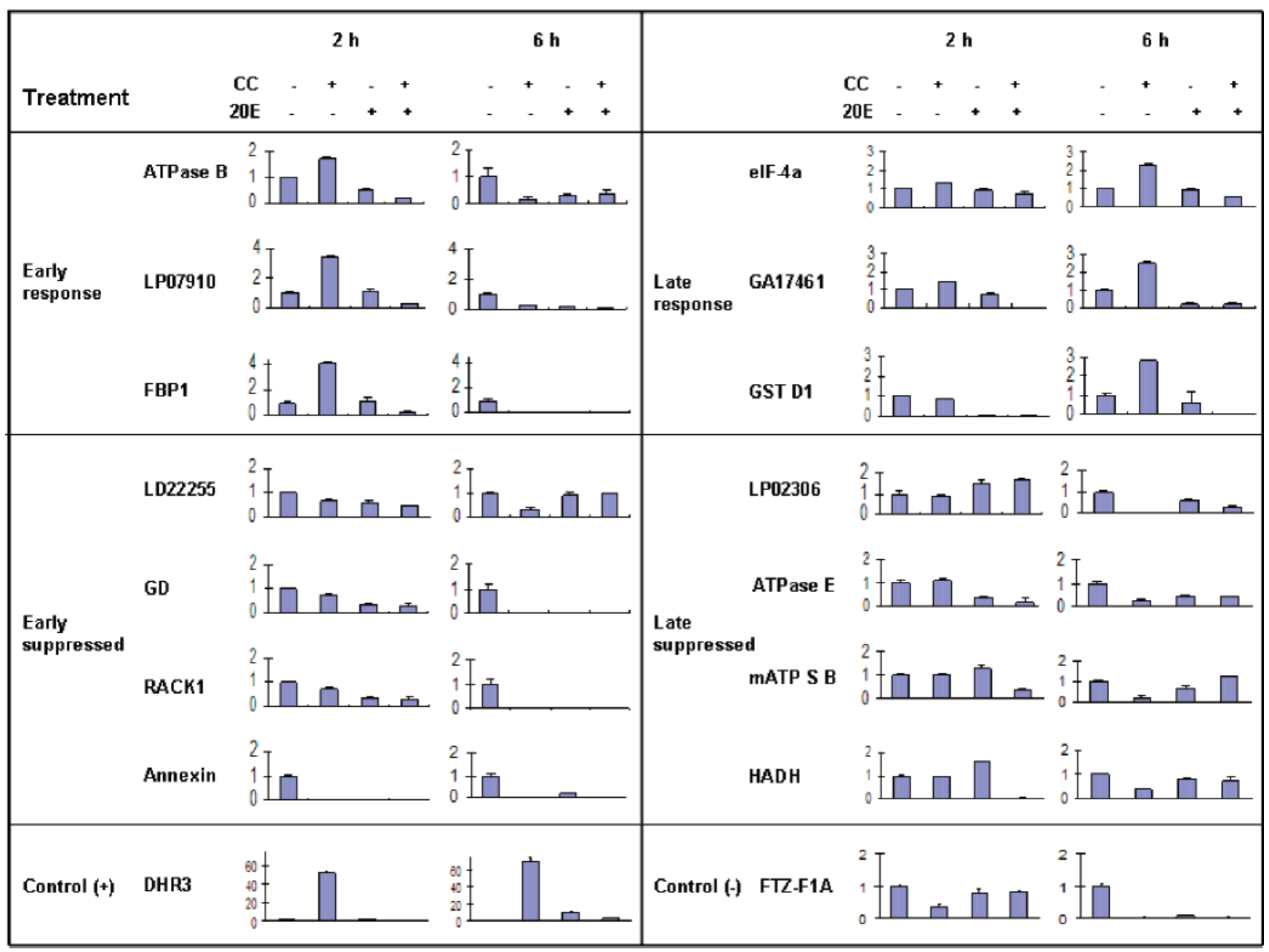

Figure 6. Real-time PCR analysis of transcription for genes encoding identified proteins. The SGs from early wandering third instar larvae of $D$. melanogaster were preincubated for $30 \mathrm{~min}$ in the presence or absence of $100 \mu \mathrm{M} \mathrm{CC}$ and then challenged for 2 and $6 \mathrm{~h}$ with or without $0.5 \mu \mathrm{M} \mathrm{20E}$. Total RNA was isolated for real-time PCR analysis of transcription levels for all 14 identified proteins. DHR3 was used as a positive control for 20E induction and FTZ-F1A as a negative control. The rp49 gene was used for normalization of the compared templates. The data represent the mean $\pm \mathrm{SE}$ of three biological samples.

genes that are not induced by $20 \mathrm{E}$ in late larval glands, i.e., the intermolt puff gene Sgs4, the stage-dependent puff gene FTZF1A, and E74B, which is normally inhibited by the 20E titers used for this study. ${ }^{10,20}$ In the present study, we investigated how PKC regulates EcR and USP subcellular localization and 20E-induced protein expression. Using CC, we showed that inhibition of PKC by its specific inhibitor resulted in the decline of EcR and USP signals in the nucleus of salivary glands in a dose- and temporal-dependent manner (Figure 2).

By itself, this finding suggests that inhibition of PKC activity by CC inhibits the expression of USP and EcR protein, increases the degradation of EcR and USP protein, or both. We speculated that the diminishing USP and EcR signals in the CCtreated glands, as shown in immunocytochemical staining (Figure 2), result from the inaccessibility of the antibodies to the EcR/USP complex caused by CC treatment under the nondenatured conditions needed for immunocytochemical staining. This prompted us to analyze EcR and USP signals in different fractions of cell lysate using the denatured SDS-PAGE and Western blot. Western blot analysis revealed that CC had no effect on total EcR and USP protein contents, a result consistent with our previous report, ${ }^{10}$ but caused a shift of both EcR and USP from the soluble nuclear fraction to the insoluble nuclear pellet (Figure 3). Combining the immunocytochemical staining data with Western blot results, it is reasonable to conclude that disappearance of USP and EcR signals from the nucleus of the PKC inhibitor-treated cells is caused by a change in the solubility of the EcR and USP complex. Moreover, it is conceivable that the transcriptional activity of USP and EcR could be affected by phosphorylation. For instance, preventing phosphorylation of USP could prevent it from fulfilling its normal role as a dimer partner for EcR, thus leading to a loss of $20 \mathrm{E}$ inducibility. The same might be true for EcR too since protein consensus recognition sequence analysis of Drosophila EcR reveals multiple phosphorylation sites for PKC. ${ }^{6}$ It is likely that PKC is also the key kinase responsible for EcR phosphorylation. Unfortunately, we do not have a good antibody to track the PKC-mediated EcR phosphorylation patterns as we did for USP. ${ }^{10}$

Alternatively, shift of the EcR/USP complex from the soluble nuclear fraction to the insoluble nuclear pellet when phosphorylation is blocked by CC might in turn indicate that the EcR/ USP dimer forms a large complex with nonphosphorylated chaperone proteins. As demonstrated by Arbeitman and Hogness, ${ }^{22}$ a functional EcR/USP complex requires six chaperone proteins. In vertebrates, prior to exposure to steroid, some 


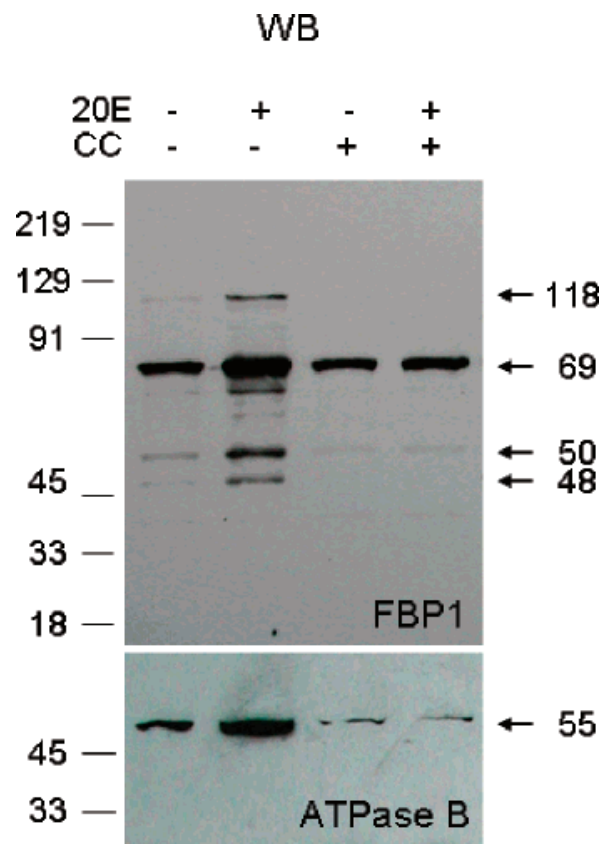

Figure 7. Western blot verification of two identified proteins. The SGs were treated for $6 \mathrm{~h}$ as described for RNA extraction and subjected to denaturing SDS-PAGE and Western blot analysis using polyclonal antibodies against FBP1 (top panel) and ATPase subunit B (bottom panel).

steroid receptors are associated with a chaperone protein complex anchored by HSP90. Upon binding to its cognate ligand, the steroid receptor dissociates from its chaperone complex, undergoes a conformational change to an active state, and ultimately regulates transcription in collaboration with a variety of transcriptional coregulatory factors. ${ }^{23,24}$ Steroid receptor activity, therefore, is regulated not only by the level of hormone but also by the levels/activity of coactivators that are recruited to target promoters to remodel chromatin and facilitate transcription. Many steroid receptors and their coregulators are phosphoproteins whose activities are regulated by diverse cell signaling pathways..$^{3,25-28}$ On the basis of the information forthcoming from this study and results obtained with EcR and other nuclear receptors, we speculate that the chaperone proteins form a complex with the EcR/USP dimer. Upon steroid hormone stimulation, the chaperone proteins are phosphorylated by protein kinases, and thereby released from the complex, thus activating receptor-mediated gene transcription. This possible mechanism bears some resemblance to the relationship of the vertebrate progesterone receptor (PR) and its chaperone proteins. Upon exposure to progesterone, the ligand-activated PR undergoes a conformational change, dissociates from chaperone proteins, dimerizes, and interacts with specific progesterone response elements in the promoter regions of target genes. The evidence from the present study illuminates the possibility that the EcR/USP complex is activated via phosphorylation of chaperone proteins. Likely, a regulatory relationship exists between nuclear sublocalization and the regulation of nuclear localization by EcR and USP, which has not yet been elucidated. ${ }^{29}$

It is critical to know whether the PKC-mediated USP phosphorylation and EcR/USP subcellular distribution ultimately affects the expression of 20E-induced proteins that are inhibited by CC addition to a medium containing 20E. The selected protein spots for MALDI-TOF MS/MS analysis were the major spots visible in Coomassie blue-stained gels, and in most cases, their expression has not previously been reported as 20Edependent. Previously identified genes whose transcriptions were induced by 20E and blocked by CC, including E74A, E75B, DHR3, E78A, and E78B, ${ }^{10}$ were not among the 14 identified proteins. The possible explanation for this is that the translational expression products of these five genes exist at trace levels and were invisible or barely visible in Coomassie bluestained gels. Moreover, while the induction of these proteins is robust, the relative molar levels of these proteins is low and possibly temporally transient, since all are associated with early transcriptional response, and normally this response has regressed by $6 \mathrm{~h}$ after the initiation of treatment.

The biggest challenges for proteomic identification of the target proteins are to validate them as true targets of $20 \mathrm{E}$ action and to confirm their identity immunologically. On the basis of the response of transcripts to $20 \mathrm{E}$ incubation for 2 and $6 \mathrm{~h}$, transcripts of the 14 genes can be roughly grouped into four categories: (1) early response, (2) late response, (3) early suppressed, and (4) late suppressed. For early and late response genes, CC inhibited 20E-induced transcription of all six genes (Figure 6), a result that correlated well with the protein level registered in 2D gel maps and implicated them as direct targets of EcR/USP action (Figure 4). ATPase subunit B and FBP1, two of three early response gene products, were also verified by Western blotting because of the availability of antibodies (Figure 7).

These results suggest that PKC-mediated phosphorylation is required for 20E-induced expression of early responsive genes at both transcriptional and translational levels. The ability to block 20E-induced DHR3 expression further implicates USP as either a direct or indirect target of CC action for offsetting the $20 \mathrm{E}$ induction of DHR3 and the other early genes, although this inference will require further testing. It is less likely that the EcR/USP heterodimer is related to the effects upon late response genes described here, thus highlighting the likelihood that CC, while specific in its molecular action, affects the transcriptional capabilities of a range of factors. In fact, the ability of CC to eliminate basal transcription belies the likelihood that other transcription factors are affected by this treatment. Moreover, the lack of correspondence for many cases, in which transcript levels are suppressed although the proteins were originally designated by their increased presence, further suggests that CC affects mechanisms associated with mRNA stability, translation, protein stability, and other processes that are not transcriptional.

The effect of 20E on synthesis of chromosomal and cytosol proteins in imaginal discs of Drosophila was reported over 25 years ago, ${ }^{30}$ but the identities of these proteins have not yet been revealed. Three of the proteins revealed by this study have been recently reported to be involved in a steroid signaling pathway. For example, RACK1 is a homologue of the G protein $\beta$ subunit and typically contains seven internal Trp-Asp 40 (WD40) repeats. ${ }^{31}$ This protein appears to be involved in at least three signal transduction pathways: the PKC pathway, ${ }^{11,32}$ the cAMP-specific phosphodiesterase PDE4D5 pathway, ${ }^{33}$ and the tyrosine kinase-phosphatase pathway. ${ }^{34,35}$ Because RACK1 interacts with several different cellular proteins associated with several signal transduction pathways, it may play a critical role in cross-talk among different signal transduction cascades. ${ }^{12,35}$ Annexin B9a is another example of a 20E-inducible gene product. ${ }^{36}$ FBP1 is expressed in the fat body. The appearance of FBP1 in SGs probably resulted from the incomplete removal 
of the fat body, which is attached to the SGs of early wandering larvae during the dissection. Nevertheless, FBP1 is an abundant protein that is also a direct target of EcR/USP action, ${ }^{37}$ and its appearance fortuitously confirms the proteomic approach as a basis for examining 20E action and the influence of PKC on the transcription of the genes encoding these proteins.

In D. melanogaster, six PKC isoforms have been identified on the basis of the available genomic sequence, ${ }^{38}$ including two classical PKCs (PKC53E and eye-PKC), two novel PKCs (PKC98E and PKCdelta), an atypical PKC (DaPKC), and a PKC-related kinase. DaPKC is essential for early embryonic development, and Eye-PKC plays a role in the regulation of visual signaling, a G-protein coupled phospholipase Cbeta-mediated cascade. No information is available on which PKC isoform is responsible for USP or EcR phosphorylation. Identification and characterization of the PKC isoform responsible for EcR and USP phosphorylation is currently underway.

In summary, the present study provides evidence that PKC mediates 20E-induced gene expression at both transcriptional and translational levels in a model system for examining steroid hormone action, the larval SG of $D$. melanogaster. Further, the recovery of known and novel early gene targets of the functional ecdysteroid receptor, as well as the effects of PKC inhibition on the subcellular localization of the receptor's partners, EcR and USP, suggests that the PKC-mediated phosphorylation is tied to their regulation of the $20 \mathrm{E}$ response.

Acknowledgment. We thank Dr. M. Huss of University of Osnabruck for polyclonal antibodies against ATPase subunit B and Dr. Jean-Antoine Lepesant of University of Paris for polyclonal antibodies against FBP1.

\section{References}

(1) Riddiford, L. M.; Cherbas, P.; Truman, J. W. Ecdysone receptors and their biological actions. Vitam. Horm. 2000, 60, 1-73.

(2) Henrich, V. The ecdysteroid receptor. In Comprehensive Molecular Insect Science; Gilbert, L. I., Ed.; Elsevier, Pergamon: Oxford, 2005; pp 243-285.

(3) Weigel, N. L. Steroid hormone receptors and their regulation by phosphorylation. Biochem. J. 1996, 319, 657-667.

(4) Lange, C. A. Making sense of cross-talk between steroid hormone receptors and intracellular signaling pathways: who will have the last word? Mol. Endocrinol. 2004, 18, 269-278.

(5) Song, Q.; Gilbert, L. I. Alterations in ultraspiracle (USP) content and phosphorylation state accompany feedback regulation of ecdysone synthesis in the insect prothoracic gland. Insect Biochem. Mol. Biol. 1998, 28, 849-860.

(6) Rauch, P.; Grebe, M.; Elke, C.; Spindler, K. D. Spindler-Barth, M. Ecdysteroid receptor and ultraspiracle from Chironomus tentans (Insecta) are phosphoproteins and are regulated differently by molting hormone. Insect Biochem. Mol. Biol. 1998, 28, $265-275$

(7) Nicolaï, N.; Bouhin, H.; Quennedey, B.; Delachambre, J. Molecular cloning and expression of Tenebrio molotor ultraspiracle during metamorphosis and in vivo induction of its phosphorylation by 20-hydroxyecdysone. Insect Mol. Biol. 2000, 9, 242-249.

(8) Song, Q.; Sun, X; Jin, X. Y. 20E-regulated USP expression and phosphorylation in Drosophila melanogaster. Insect Biochem. Mol. Biol. 2003, 33, 1211-1218.

(9) Thummel, C. S. Ecdysone-regulated puff genes 2000. Insect Biochem. Mol. Biol. 2002, 32, 113-120.

(10) Sun, X.; Song, Q. PKC-mediated USP phosphorylation is required for 20E-induced gene expression in the salivary glands of Drosophila melanogaster. Arch. Insect Biochem. Physiol. 2006, 62, 116127.

(11) Ron, D.; Jiang, Z.; Yao, L.; Vagts, A.; Diamond, I.; Gordon, A. Coordinated movement of RACK1 with activated $\beta$ IIPKC. J. Biol. Chem. 1999, 274, 27039-27046.
(12) Rigas, A. C.; Ozanne, D. M.; Neal, D. E.; Robson, C. N. The scaffolding protein RACK1 interacts with androgen receptor and promotes cross-talk through a protein kinase C signaling pathway. J. Biol. Chem. 2003, 278, 46087-46093.

(13) Quan, G. X.; Krell, P. J.; Arif, B. M.; Feng, Q. Receptor of activated C kinase 1 (RACK1) is necessary for the 20-hydroxyecdysoneinduced expression of the transcription factor CHR3 in the spruce budworm Choristoneura fumiferana. Insect Mol. Biol. 2006, 15 (1), 79-87.

(14) Andres, A. J.; Thummel, C. S. Methods for quantitative analysis of transcription in larvae and prepupae. Methods Cell Biol. 1994, 44, 565-573.

(15) Alnemri, E. S.; Fernandes-Alnemri, T. D.; Nelki, S.; Dudley, K.; DuBois, G. C.; Litwack, G. Overexpression, characterization and purification of a recombinant mouse immunophilin FKBP-52 and identification of an associated phosphoprotein. Proc. Natl. Acad. Sci. 1993, 90 (14), 6839-6843.

(16) Havlis, J.; Thomas, H.; Sÿ, ebela, M.; Shevchenko, A. Fast-response proteomics by accelerated in-gel digestion of proteins. Anal. Chem. 2003, 75, 1300-1306.

(17) Jiménez, C. R.; Huang, L.; Qiu, Y.; Burlingame, A. L. In-gel digestion of proteins for MALDI-MS fingerprint mapping. In Current Protocols in Protein Science; Coligan, J. E., Ed.; John Wiley \& Sons, Inc.: Brooklyn, NY, 1998; pp 16.4.1-16.4.5.

(18) Livak, K. J.; Schmittgen, T. D. Analysis of relative gene expression data using real-time quantitative PCR and the 2(-Delta Delta C(T)) Method. Methods 2001, 25, 402-408.

(19) Hiruma, K.; Riddiford, L. M. Differential control of MHR3 promoter activity by isoforms of the ecdysone receptor and inhibitory effects of E75A and MHR3. Dev. Biol. 2004, 272, 510521.

(20) Karim, F. D.; Thummel, C. S. Ecdysone coordinates the timing and amounts of E74A and E74B transcription in Drosophila. Genes Dev. 1991, 5, 1067-1079.

(21) Burmester, T.; Antoniewski, C.; Lepesant J. A. Ecdysone-regulation of synthesis and processing of Fat Body Protein 1, the larval serum protein receptor of Drosophila melanogaster. Eur. J. Biochem. 1999, 262 (1), 49-55.

(22) Arbeitman, M. N.; Hogness, D. S. Molecular chaperones activate the Drosophila ecdysone receptor, an RXR heterodimer. Cell 2000, 101, 67-77.

(23) Pratt, W. B.; Toft, D. O. Steroid receptor interactions with heat shock protein and immunophilin chaperones. Endocr. Rev. 1997, $18,306-360$

(24) Cheung, J.; Smith, D. F. Molecular chaperone interactions with steroid receptors: an update. Mol. Endocrinol. 2000, 14, 939946.

(25) Wu, R. C.; Qin, J.; Yi, P.; Wong, J.; Tsai, S. Y.; Tsai, M. J.; O'Malley, B. W. Selective phosphorylations of the SRC-3/AIB1 coactivator integrate genomic reponses to multiple cellular signaling pathways. Mol. Cell 2004, 15, 937-949

(26) Lopez, G. N.; Turck, C. W.; Schaufele, F.; Stallcup, M. R.; Kushner, P. J. Growth factors signal to steroid receptors through mitogenactivated protein kinase regulation of p160 coactivator activity. J. Biol. Chem. 2001, 276, 22177-22182

(27) Weigel, N. L.; Zhang, Y. Ligand-independent activation of steroid hormone receptors. J. Mol. Med. 1998, 76, 469-479.

(28) Rowan, B. G.; Garrison, N.; Weigel, N. L.; O'Malley, B. W. 8-Bromo-cyclic AMP induces phosphorylation of two sites in SRC-1 that facilitate ligand-independent activation of the chicken progesterone receptor and are critical for functional cooperation between SRC-1 and CREB binding protein. Mol. Cell. Biol. 2000, $20,8720-8730$.

(29) Nieva, C.; Gwozdz, T.; Dutko-Gwozdz, J.; Wiedenmann, J.; Spindler-Barth, M.; Wieczorek, E.; Dobrucki, J.; Dus, D.; Henrich, V.; Ozyhar, A.; Spindler, K. D. Ultraspiracle promotes the nuclear localization of ecdysteroid receptor in mammalian cells. Biol. Chem. 2005, 386, 463-470.

(30) Hill, R. J.; Watt, F.; Yund, M. A.; Fristrom, J. W. The effect of 20hydroxyecdysone on synthesis of chromosomal and cytosol proteins in imaginal discs. Dev. Biol. 1982, 90, 340-351.

(31) Ron, D.; Chen, C. H.; Caldwell, J.; Jamieson, L.; Orr, E.; MochlyRosen, D. Cloning of an intracellular receptor for protein kinase C: a homolog of the $\beta$ subunit of G proteins. Proc. Natl. Acad. Sci. 1994, 91, 839-843.

(32) Ron, D.; Luo, J.; Mochly-Rosen, D. C2 region-derived peptides inhibit translocation and function of beta protein kinase $\mathrm{C}$ in vivo. J. Biol. Chem. 1995, 270, 24180-24187. 
(33) Yarwood, S. J.; Steele, M. R.; Scotland, G.; Houslay, M. D.; Bolger, G. B. The RACK1 signaling scaffold protein selectively interacts with the cAMP-specific phosphodiesterase PDE4D5 isoform. $J$. Biol. Chem. 1999, 274, 14909-14917.

(34) Chang, B. Y.; Conroy, K. B.; Machleder, E. M.; Cartwright, C. A RACK1, a receptor for activated C kinase and a homolog of the $\beta$ subunit of G proteins, inhibits activity of Src tyrosine kinases and growth of NIH 3T3 cells. Mol. Cell. Biol. 1998, 18, 3245-3256.

(35) McCahill, A.; Warwicker, J.; Bolger, G. B.; Houslay, M. D.; Yarwood, S. J. The RACK1 scaffold protein: a dynamic cog in cell response mechanisms. Mol. Pharmacol. 2002, 62, 1261-1273.
(36) Tsuzuki, S.; Iwami, M.; Sakurai, S. Ecdysteroid-inducible genes in the programmed cell death during insect metamorphosis. Insect Biochem. Mol. Biol. 2001, 31, 321-331.

(37) Antoniewski, C.; Laval, M.; Dahan, A.; Lepesant, J. A. The ecdysone response enhancer of the Fbpl gene of Drosophila melanogaster is a direct target for the EcR/USP nuclear receptor. Mol. Cell. Biol. 1994, 14 (7), 4465-4474.

(38) Shieh, B. H.; Parker, L.; Popescu, D. Protein kinase C (PKC) isoforms in Drosophila. J. Biochem. 2002, 132 (4), 523-527.

PR0705183 